\title{
COMMENTS
}

\section{THE INFLUENCE OF THE ISLAMIC LAW OF WAQF ON THE DEVELOPMENT OF THE TRUST IN ENGLAND: THE GASE OF MERTON COLLEGE}

\author{
Monica M. Gaudiosi $\dagger$
}

Oxford University would seem to represent the quintessential English academic institution. Yet, in its early phases of development, Oxford may have owed much to the Islamic legal institution of waqf (pl. awqaf), charitable trust. ${ }^{1}$

The incorporation of Merton College, Oxford, in 1274, is generally considered to mark the foundation of the modern college system. ${ }^{2}$ The other colleges at Oxford, as well as Cambridge and myriad other institutions, accepted the Regula Mertonensis as embodying the ideal collegiate structure. ${ }^{3}$ In its original form, however, the House of the

† B.A. 1984, M.A. Candidate 1988, J.D. Candidate 1988, University of Pennsylvania.

1 A number of Arabic legal terms will be used throughout this Comment. These terms, along with their English equivalents, are as follows:

wagf (pl. awqaf)-charitable trust;

wagf khairi-a charitable trust that provides both the remainder and current income to a religious or public purpose;

wagf ahli, waqf dhurri-a charitable trust that provides the remainder to a religious or public purpose after the expiration of a preceding noncharitable income interest; qurba-closeness to God through the performance of good works;

Sunni-belonging to one of the main branches of Islam. Today, the vast majority of Muslims are Sunni;

Hanafi, Hanbali, Maliki, Shafici-belonging to a particular school of law within Sunni Islam. These four are the only schools still in existence. See infra note 16;

wagif-founder of a trust;

qadi-judge;

mutawalli-trustee;

madrasa (pl. madaris)-Islamic college of law, ordinarily a waqf institution.

${ }^{2}$ See J. Highfield, The Early Rolls of Merton College Oxford

54 (1964); Makdisi, The Guilds of Law in Medieval Legal History: An Inquiry into the Origins of the Inns of Court, 34 CLEv. ST. L. REV. 3, 15 (1985-86).

3 The Regula Mertonensis was the system of collegiate government found in the 1274 Statutes of Merton College. See J. Highfield, supra note 2, at 54; E. Hobhouse, Bishop of Nelson, Sketch of the Life of Walter de Merton 29 (1859). 
Scholars of Merton was a simple, unincorporated charitable trust, markedly similar to the Islamic waqf. ${ }^{4}$

Several scholars of Islamic law have suggested that Islamic influence was prominent in the development of the English trust. These studies are largely confined to general, rather abstract comparisons of the two institutions. ${ }^{5}$ This theory of Islamic influence, however, has received little attention from Western legal scholars, who instead have pursued other theories, based on Roman and Germanic law. ${ }^{6}$ It is the purpose of this Comment to reexamine the theory of Islamic influence and to apply it directly to a thirteenth-century English legal document: the 1264 Statutes of Merton College. ${ }^{7}$

Part I of this Comment outlines the Islamic law of charitable trusts in order to familiarize the reader with this highly developed body of law. Part II discusses theories of the origin of the English trust and demonstrates the superiority of a theory of Islamic influence over the prevailing theory based on Germanic law. Finally, Part III consists of a close reading of the 1264 Statutes of Merton College, identifying the many similarities between that document and the typical waqf instrument that support the theory of Islamic influence. Perhaps this more concrete analysis will stimulate greater inquiry into the influence of Islamic law on the development of Western law. ${ }^{8}$

\section{THE LAW OF WAQF}

Not surprisingly, the following discussion of the law of waqf details many overtly "religious" elements. Islamic law is a sacred law, "compris[ing] on an equal footing ordinances regarding worship and ritual, as well as political and (in the narrow sense) legal rules."

- See Makdisi, supra note 2, at 15.

- See, e.g., Cattan, The Law of Wagf, in Law IN THE Middle East 203, 212-18 (1955) (describing general similarities and differences between the waqf and the early English trust or use); Thomas, Note on the Origin of Uses and Trusts-Waqfs, 3 Sw. L.J. 162 (1949) (providing a brief description of the waqf and noting the hypothesis that the waqf may have affected the development of the English trust).

- See infra notes 88-121 and accompanying text (discussing theories of Roman and Germanic influence on the English trust).

7 The term "statute" refers to "an act of a ... founder intended as a permanent rule or law," as in the statutes of a university. See WEBSTER's THIRD NEw INTERNATIONAL DictionaRY 2230 (1981). Statutes, in this sense, are likened to corporate acts of analogous intent and authority. See id. For a translation of the 1264 statutes of Merton College, see Appendix, infra.

${ }^{8}$ For additional scholarly commentary comparing Islamic law and the Western legal tradition, see generally Conference on Comparative Links Between Islamic Law and the Common Law, 34 Clev. ST. L. Rev. 1 (1985-86).

$9 \mathrm{~J}$. SCHACHT, AN InTROdUCtION TO IsLamic LAW 1 (2d impression 1966). Elsewhere, Schacht describes Islamic law as "compris[ing] . . . an infallible doctrine of 
Thus, "each institution, transaction, or obligation is measured by the standards of religious and moral rules."10 These rules were developed through analogical reasoning by Muslim jurists, specialists in Islamic jurisprudence-the preeminent Islamic science. ${ }^{11}$

\section{A. Definition}

Within the first three centuries of Islam (the seventh, eighth, and ninth centuries A.D.) Muslim jurists developed the legal institution known as the waqf, an unincorporated charitable trust. ${ }^{12}$ Two types of waqf existed: the waqf khairi-an endowment for an object of a religious or public nature-and the waqf ahli or dhurri-a family endowment. ${ }^{13}$ This Comment is primarily concerned with the former. In either case, the ultimate purpose of the waqf was qurba, the performance of a work pleasing to God. Accordingly, even a wagf ahli would ultimately devolve to a charitable purpose, though not until some precondition was filled such as the passing of a certain number of generations or the extinction of the family line. ${ }^{14}$ The waqf form was commonly used to endow mosques, colleges, hospitals, and other charitable institutions, and a complex body of law emerged to govern the creation and administration of these trusts. ${ }^{16}$

According to the Hanafi school of law, one of the four Sunni

ethics [for] the whole religious, political, social, domestic and private life of those who profess Islam, to the fullest extent without limitation and that of the tolerated members of other faiths in so far as their activities are not inimical to Islam." Schacht, Sharic ${ }^{\circ}$, in 7 The ENCYCLOPAEDIA of IsLAM 320, 321 (1934). The sharic $a$, religious law, may be divided into three categories: ${ }^{c}$ ibadat, obligations regarding worship; $m u^{c}$ amalat, civil/legal obligations; and $c_{u q u b a t}$, punishments. See id. The law of wagf would fall into the second category. For further discussion of the nature of Islamic law, see generally I. Goldziher, Introduction to Islamic Theology and Law; J. Schacht, supra, at 199-211.

$10 \mathrm{~J}$. ScHACHr, supra note 9, at 201.

11 See id. at 1, 5. Schacht notes that "Islamic law represents an extreme case of a 'jurists' law'; it was created and further developed by private specialists." Id. at 209. For a discussion of Islamic jurisprudence, see Schacht, Fikh, in 2 THE ENCYCLOPAEDIA OF Islam 886 (new ed. 1965). See also Schacht, Pre-Islamic Background and Early Development of Jurisprudence, in LAW IN THE MiddLe EAST, supra note 5, at 28; Schacht, The Schools of Law and Later Developments of Jurisprudence, in LAw IN THE MIDDle EAST, supra note 5, at 57.

12 See Cattan, supra note 5, at 205.

${ }^{13}$ While the concepts of both religious and family endowments existed in the medieval period, the terminology distinguishing the two appears to be modern. Such terminology will be used herein, however, to avoid confusion.

14 See Cattan, supra note 5, at 203; Heffening, Wakf, in 8 The Encyclopaedia of IsLam 1096, 1096 (1928).

${ }^{15}$ See G. Makdisi, The Rise of Colleges 38 (1981). Other known wagf objects included bridges, alms, and the release of prisoners of war. See id. 
schools of law still in existence, ${ }^{16}$ a waqf was "the detention of the corpus from the ownership of any person and the gift of its income or usufruct either presently or in the future, to some charitable purpose." "17 While ownership of the waqf property was thereby relinquished by the founder, it was not acquired by any other person; ${ }^{18}$ rather, it was " "arrested" " or " "detained." "19 The trust itself was not a juristic person, as is the modern corporation, for no such concept is recognized in Islamic law. ${ }^{20}$ The beneficiaries of the trust, however, had a legal interest in the usufruct of the wagf property. ${ }^{21}$

\section{B. Conditions of Validity}

As a preliminary to any discussion of the law of waqf, it must be noted that modern works on the Islamic trust are based on a relatively small number of documents. Few waqf instruments are extant, and contemporary references to awqaf are often fragmentary or specific to individual institutions. This discussion is therefore a generalized overview, for while awqaf "shared in a great number of characteristics . . their differences could also be great."22

Three basic principles governed the waqf: the trust was required to be irrevocable, perpetual, and inalienable. ${ }^{23}$ Once property was declared waqf by its owner, the trust thereby created was irrevocable. The owner, known as the waqif, founder, could retain certain rights as to its

16 The four Sunni schools of law still in existence are the Hanafi, Hanbali, Maliki, and Shafi ${ }^{i} i$ schools. They are known as "personal schools," that is, "groups ... designated as followers of a leading jurisconsult." Id. at 1 . Such schools are considered equally orthodox. See id. The law of waqf was quite similar among the schools; any significant differences will be noted.

For a discussion of the Sunni schools of law, including their development, doctrines, and geographical spheres of influence, see generally Heffening, al-Shafi $C_{i}$, in 7 THE ENCYCLOPAEDIA OF ISLAM 252 (1934) (discussing the Shafi $c_{i}$ school and its eponym, ash-Shafi $\mathrm{i}$ ); Heffening[-Schacht], Hanafiyya, in 3 The Encyclopaedia of IsLAM 162 (new ed. 1971) (discussing the Hanafi school and its eponym, Abu Hanifa); Laoust, Hanabila, in 3 THE ENCYClOPAEDIA OF IsLAM 158 (new ed. 1971) (discussing the Hanbali school and its eponym, Ahmad b. Hanbal); Schacht, Malik b. Anas, in 5 The Encyclopaedia of Islam 205 (1936) (discussing the Maliki school and its eponym, Malik b. Anas). For a more general discussion of the role of these schools in Islamic jurisprudence, see G. MAKDISI, supra note 15, at 1-9.

17 Cattan, supra note 5 , at 203.

Usufruct is the "right of enjoying the use and advantages of another's property short of destruction or waste of its substance." See CoNCISE OXFORD Dictionary of CurRent English 1183 (7th ed. 1982).

${ }_{18}$ See Cattan, supra note 5, at 208.

18 See id. at 203.

20 See Heffening, supra note 14, at 1097.

21 See Cattan, supra note 5, at 208.

22 G. MAKDISI, supra note 15 , at 37.

${ }^{23}$ See Cattan, supra note 5, at 206. 
administration, but the endowment itself was invalid unless irrevocable, ${ }^{24}$ and the waqif was bound by the terms of the waqf document. ${ }^{25}$ Likewise, the creation of the wagf could not be made dependent on the actions of any third party, nor was a conventional option clause permissible. ${ }^{26}$

The wagf was also perpetual, although the specific object of the trust need not have been permanent. Rather, the requirement of perpetuity referred to the dedication of the income of the waqf to charitable purposes. Should the specific purpose for which the trust was created cease to exist, the waqf income was applied to a similar charitable object. ${ }^{27}$ The Maliki school of law did allow the creation of a wagf "limited as to time or as to a life or series of lives," at the expiration of which full ownership of the property reverted to the founder or the founder's heirs. ${ }^{28}$ This, however, was the exception to the generally accepted rule of perpetuity.

Wagf property was also inalienable and could not be the subject of "any sale, disposition, mortgage, gift, inheritance, attachment, or any alienation whatsoever."28 The property could be exchanged for equivalent property, however, and if the waqif reserved the right to do so, or if the original waqf property fell into ruin and ceased to produce income, the property could even be sold, provided that the price received was reinvested in another property. ${ }^{30}$

Other conditions governed the creation of the wagf as well. The waqif, for example, was required to "be in full possession of his physical and mental faculties, be of age and a free man." ${ }^{31} \mathrm{He}^{32}$ must also

24 See id. at 210.

25 See G. MAKDISI, supra note 15 , at 36.

${ }^{26}$ See id. at 38-39. An options clause, khiyar, is the "right of withdrawal, i.e. the right for the parties involved to terminate the legal act unilaterally." Delcambre, Khiyar, in 5 The ENCYClopaedia of Islam 25, 25 (new ed. 1986). Khiyar ash-shart, the "conventionary" clause most relevant to the law of waqf, is a "purely potestative suspensory condition," allowing one or both parties to reserve "the right to annul or to confirm, within a specified time, the legal act which they have just drawn up." Id. Such an option would violate the principle of irrevocability.

27 See G. MAKDISI, supra note 15 , at 39.

28 Cattan, supra note 5, at 207.

28 Id. at 208.

so See id. Note, however, that "[t]he power to sell or exchange [was] very strictly exercised and waqf property [could] not, generally speaking, be sold in exchange for another property merely because the resulting increase in the corpus would be beneficial to the waqf." Id. at 208-09.

${ }^{31}$ Heffening, supra note 14, at 1096; see also Cattan, supra note 5, at 205 (requiring the waqif to "be of age and sound mind and [the owner of] the property that he intends to make waq?").

${ }^{32}$ While it is the policy of The University of Pennsylvania Law Review to use "she" as the generic pronoun, the masculine will be used throughout this Comment. While women could own property under both Islamic and English law in the periods 
have unrestricted ownership of the property declared waqf. ${ }^{33}$ The property constituting the trust must itself be tangible and immobile ${ }^{34}$ and must yield income. ${ }^{35}$ Real estate was therefore the property most commonly made $w a q f^{36}$

Islamic law mandated no particular form to create a waqf. It simply required the waqif to indicate clearly his intention to create the trust and to specify the charitable purpose to which the trust would be dedicated. ${ }^{37}$ The waqif could make this declaration either orally or in writing, ${ }^{38}$ and, typically, he used certain words to express intent. ${ }^{39}$ The waqif need not, however, deliver the property to its designated trustee, the mutawalli, for the trust to be valid. ${ }^{40}$ The qadi, judge, held the wagf instrument and was the general overseer of the administration of the trust. ${ }^{41}$

The waqif had considerable latitude in setting forth the terms and conditions of the operation of the trust. ${ }^{42}$ These terms could include, but were not limited to, stipulations governing the appointment of the mutawalli, the selection of beneficiaries, and the distribution of waqf income. ${ }^{43}$ The founder could appoint himself trustee of the waqf ${ }^{44}$ or reserve to himself the power to appoint ${ }^{45}$ and/or dismiss the

discussed, women rarely possessed the type of wealth necessary to endow a trust. Exceptions did exist, however. See, e.g., Makdisi, On the Origin and Development of the College in Islam and the West, in IsLAM aND THE MEDIEval WEST: AsPects of INTERCUlTURAL RELATIONS 26, 32 \& n.22 (1980) (discussing the charitable activities of the mother of the Caliph al-Muqtaddi).

${ }^{33}$ See Heffening, supra note 14, at 1096.

${ }^{34}$ See G. MAKDISI, supra note 15 , at 38 . Certain movables, however, may be made wagf; these include "animals for their milk and wool, trees for their fruits, slaves for their labour, [and] books for study." Heffening, supra note 14, at 1096.

${ }^{35}$ See Heffening, supra note 14, at 1096.

${ }^{36} I d$.

${ }^{37}$ See id. at 1097.

${ }^{38}$ See id. at 1096-97 (observing that written declarations were most common).

39 See id. at 1097. The waqif phrased his dedication by commencing with waqaftu, habbastu, or sabbaltu, see id., all with the technical meaning of "I bequeath as a charitable endowment."

40 See Cattan, supra note 5, at 205-06.

41 See G. MAKDISI, supra note 15, at 38, 55; see also infra text accompanying notes 63-69 (detailing the duties of the qadi).

${ }^{22}$ See G. MAKDISI, supra note 15 , at 35 .

43 See Cattan, supra note 5, at 210.

44 See G. MAkdisI, supra note 15, at 36. Under Maliki law, however, the founder could not serve as trustee for his own wagf. See id. at 37-38. This feature may have been the primary reason for the relative scarcity of Maliki trusts and the general decline of the Maliki school in the major centers of the Islamic Empire. See id. at 38. Due to the Maliki restriction on the role of the waqif, fewer trusts were established under Maliki law. Such trusts were the primary source of support for madaris, Islamic colleges of law. Thus, the decline in the number of madaris resulted in a decline in the number of jurists trained in the Maliki tradition. See id.

4o See id. at 51 . 
mutawalli. ${ }^{46}$ The waqif could also retain the right to modify the terms of the waqf, repeatedly if desired." In general, "[t]he wishes of the waqif are carried out in perpetuity with a force equal to that of a legal enactment." 48 However, the terms set forth by the founder could not violate any of the tenets of Islam. ${ }^{49}$ Thus, a waqf for the construction of a church or synagogue would be invalid, as would a trust for any institution propagating doctrines inimical to Islam. ${ }^{30}$

A waqf was void without an ultimate charitable object. ${ }^{31}$ Thus, outwardly at least, the motive for the creation of a charitable trust was to perform good works and please God. Only this declared motive was relevant to the validity of the trust. As the only form of perpetuity in Islam, however, founders used the law of waqf for a variety of undeclared, nonreligious purposes. These included avoidance of confiscation of property by rulers, tax avoidance, control over an heir's excesses, and currying favor with the religious leadership and, through them, with the masses. ${ }^{52}$ Confiscation, for example, was so common that one eleventh-century historian pointed out those rulers who did not follow such a policy. ${ }^{53}$

\section{Participants in the Waqf}

The founder, the trustee, the judge/overseer, and the beneficiaries were the primary actors in the creation and/or administration of the waqf. ${ }^{\text {s4 }}$ The role of the waqif, founder, has been discussed in the foregoing Section. ${ }^{\text {s }}$

\section{The Trustee}

Every waqf was required to have a mutawalli, trustee, the first of whom the founder ordinarily appointed in the waqf document. This trustee implemented the wishes of the waqif as expressed in the wagf

16 See id. at 54.

47 See id. at 36.

18 Cattan, supra note 5, at 210.

49 See G. MAKDIsI, supra note 15 , at 36 .

so See id. at 39; Heffening, supra note 14, at 1096.

51 See G. Makdisr, supra note 15 , at 38 .

${ }^{52}$ See id. at 39.

5s See id. at 40 .

64 The technical term for beneficiary is mustahiqq (pl. mustahiqqun). However, beneficiaries were more often identified by their titles or positions within the trust. In an academic institution, such positions would include professor, scholar, and prayer leader. $C$ f. G. MAKDISI, supra note 15, at 59 (identifying categories of beneficiaries in the waqf instrument of the Shamiya College of Law).

os See supra notes $22-53$ and accompanying text. 
instrument. ${ }^{56}$ The selection of subsequent trustees occurred in the manner prescribed by the waqif in that document or, in the absence of such a provision, through appointment by the qadi, judge. ${ }^{57}$ In general, a mutawalli was required to be "Muslim, legally responsible, [and] able to carry out his functions with knowledge and experience." mutawalli was found to be morally weak, a strong, honorable person could be appointed to assist him. ${ }^{59}$

Among the primary duties of the trustee, as described by the Muslim jurists, were preservation of the waqf, collection of waqf income, distribution of that income to the appropriate beneficiaries, hiring and firing of subordinates, and resolution of disputes. ${ }^{60}$ In the course of carrying out his duties, the trustee could hire subordinates and delegate certain tasks to them. ${ }^{61}$ Even where the mutawalli was given free rein in his administration of the waqf, he was required to act within the boundaries of Islamic law, and any decisions regarding the waqf were to be made for the common good. ${ }^{62}$

\section{The Judge}

The local qadi served as a general overseer of awqaf within his jurisdiction. ${ }^{63}$ His power to oversee extended to the discretion to appoint a trustee in the event that the waqif neither designated a mutawalli nor set forth criteria for his appointment. ${ }^{64}$ In some cases, the qadi himself then took on the post of trustee. ${ }^{85}$ With a trustee in place, the qadi was obliged to respect the mutawalli's rights with regard to the day-to-day operation of the waqf, ${ }^{68}$ but the qadi could, with cause, ${ }^{67}$ dismiss the trustee. ${ }^{68}$ Most importantly, the qadi was responsi-

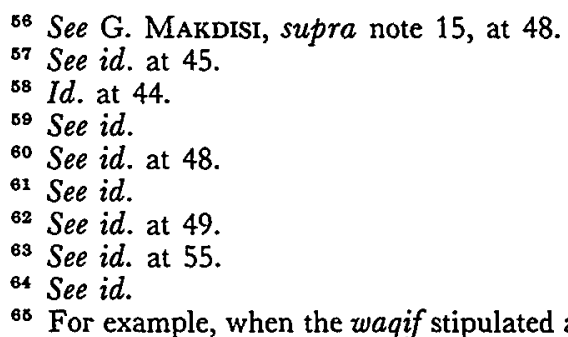
that failed to produce a qualified candidate, the post devolved to the qadi. Thus, if the waqif required that the most "level-headed" of his progeny be selected mutawalli and there was no longer "one of sound character" in the founder's line of descent, the qadi would fill the post. See id. at 55 .

B6 See id.

67 "Cause" included embezzlement or breach of trust, see id. at 55-56, or simply neglect of duty, see Heffening, supra note 14, at 1097.

${ }^{68}$ See G. MakdisI, supra note 15, at 55-56. While the qadi could dismiss a trustee appointed by the founder only for cause, the qadi could dismiss his own appointee even without cause. See id. 
ble for resolving all disputes concerning waqf matters in which he was not personally involved, and his decision in that regard was final. ${ }^{69}$

\section{The Beneficiaries}

The beneficiaries designated by the waqif were entitled to share in the usufruct of the waqf. ${ }^{70}$ They were not the owners of the waqf property. The beneficiaries were to receive the share allotted them by the waqif, even if one of the founder's stipulations had to be ignored to ensure adequate compensation. ${ }^{71}$ These beneficiaries, however, were entitled only to such a share as long as they complied with the conditions of the waqf instrument. ${ }^{72}$ Indeed, a beneficiary who failed to perform his duties could be dismissed by the mutawalli and replaced with another. ${ }^{73}$ The mutawalli took such drastic measures, however, only if the beneficiary violated a specific, clearly expressed stipulation. If the stipulation at issue was ambiguous, the beneficiary was given "the benefit of the doubt."74

The beneficiaries did receive some rights along with these responsibilities. They had the right to acquaint themselves with their duties and "to be as informed as the mutawalli" regarding the provisions of the wagf document. ${ }^{75}$ To this end, they could request a copy of the waqf instrument. ${ }^{78}$

This then is a general overview of the law of waqf. Part II com-

60 See id. at 56.

70 See id. at 60 .

71 For example, when the wagf instrument provided that beneficiaries were to receive a specified stipend and also forbade beneficiaries from enjoying the benefits of a second waqf, a conflict could arise when the waqf failed to provide adequate income to pay the specified stipend. In such a situation, the condition prohibiting the beneficiary from participating in a second waqf could be ignored. See G. MAKDISI, supra note 15, at $60-61$.

The wagf property, however, could not be consumed to meet current income requirements. Thus, if the rent from wagf realty was insufficient to pay the beneficiaries their specified stipend, a portion of the realty could not be sold to provide funds for the stipend. See id. at 50. "The beneficiaries could share in the usufruct of the waqf, not in its substance." Id. at 60 .

${ }_{72}$ See id. at 60 . In a waqf khairi, the founder could "stipulate in the waqf instrument that the[] beneficiaries were not to benefit from other waqfs." Id. at 61. In a wagf $a h l i$, a beneficiary could forfeit all right "upon contracting debts or upon marriage, or upon marriage into other than a designated family." Cattan, supra note 5 , at 211 . The Hanbali and Maliki schools, however, "do not recognize as legitimate [these] conditions which arbitrarily deprive beneficiaries of their rights." Id.

${ }^{73}$ See G. MAKDISI, supra note 15 , at 62 .

34 Id. at 60 . For example, "a student absenting himself from [a charitably endowed] college for a few days was considered not to have been delinquent, because the waqf did not specifically call for his presence every school day." Id.

${ }^{75}$ Id.

${ }^{76}$ See id. 
pares the waqf form with that of the early English trust and examines the theory of Islamic influence on the development of the trust in England.

\section{Conflicting Theories on the Origin of the Trust in England}

While Western legal scholars dispute the origin of the trust in England, whether Roman or Germanic, it is well established that the institution "developed from a medieval English device for holding land known as the use." In Indeed, until the enactment of the Statute of Uses $^{78}$ in 1535 , trusts were commonly referred to as uses. ${ }^{79}$

The Franciscan Friars are generally credited with the introduction of uses in thirteenth-century England. ${ }^{80}$ Under the laws of their Order, the Friars were not permitted to own property. They could, however, be named the beneficiaries of a use. ${ }^{81}$ This arrangement was soon expanded to other contexts as well, for it provided a beneficiary with all of the benefits and none of the liabilities of land ownership. ${ }^{82}$

In form, the owner of the property, the feoffor, gave legal estate in that property to the "feoffee to uses." vested with the full ownership rights of the feoffor. The feoffee to uses, however, was bound to exercise his rights over the property for the

77 Fratcher, Uses of Uses, 34 Mo. L. REv. 39, 39 (1969).

${ }^{28}$ An Act Concerning Uses and Wills, 27 Hen. 8, ch. 10 (1535), reprinted in 15 The Complete Statutes of England 51 (1930). The Statute of Uses was designed to curb the abuse of this device by turning the purely equitable interest of the beneficiary into a legal interest and destroying the legal interest of the trustee. See $1 \mathrm{~A}$. ScotT, The Law of Trusts $\S 67$ (3d ed. 1967). But see Hopkins v. Hopkins, 26 Eng. Rep. 365, 372 (Ch. 1738) ("[A] statute made upon great consideration, introduced in a solemn and pompous manner, by this strict construction, has had no other effect than to add at most, three words to a conveyance."). For a discussion of the Statute of Uses, see C. Moynihan, Introduction to the Law of Real Property 181-84 (1962); 1 A. ScoTt, supra, \& 1.5. (1935).

${ }_{79}$ Brown, The Ecclesiastical Origin of the Use, 10 Notre Dame Law. 353, 353

so See, e.g., Cattan, supra note 5, at 213 (tracing back to the second quarter of the thirteenth century uses created for the benefit of Franciscan Friars).

81 See Maitland, The Origin of Uses, 8 HARv. L. REv. 127, 130 (1894).

82 See 4 W. Holdsworth, A History of ENGlish Law 417 (3d ed. 1945). A passive use could enable a family to circumvent outdated laws of land ownership, such as primogeniture. See Fratcher, supra note 77, at 45 ; see also infra note 87 and accompanying text.

83 "A person to whom land was conveyed for the use of a third party." BLACK's Law Dictionary 557 (5th ed. 1979). Prior to the passage of the Statute of Uses, see supra note 78, the feoffee to uses, who was directed "to hold the land for the benefit of other persons," had bare legal title; the cestui que use, see infra note 85, held the beneficial ownership. P. Pettrt, EQuity and the Law of Trusts 9 (3d ed. 1974). 
benefit of another, ${ }^{84}$ known as the cestui que use. ${ }^{85}$

Most uses were passive. The legally imposed duties of the feoffee to uses were: "(1) to permit the cestui que use to occupy the land and enjoy the rents and profits; (2) to defend the title in actions at law by and against third parties; and (3) to convey the land as directed by the cestui que use." ${ }^{186}$ From the earliest stages of the use, however, active trusts existed providing for efficient management of the property, and were employed, for example, while the beneficiary was on crusade. ${ }^{\mathbf{8 7}}$

\section{A. The Roman Fideicommissum}

Until the nineteenth century, legal scholars considered the Roman fideicommissum to be the origin of the trust in England. ${ }^{88}$ Under this device,

[w]hen a Roman testator found that his prospective beneficiary was incapacitated to receive a testament, he transmitted to his legatee the intended legacy through a person capable of receiving[,] . . . trusting . . . that the legal beneficiary would honor his moral obligation and pass the legacy to the real beneficiary of the trust. ${ }^{89}$

By the nineteenth century, this theory had been replaced by one focusing on Germanic influences, ${ }^{80}$ with scholars agreeing that any analogies between the fideicommissum and the use were "merely . . . of a superficial kind."

A specific criticism of the theory was that the Roman device was purely testamentary, while the early English use seldom arose by will. ${ }^{92}$ This evinces a divergence of purpose between the two transactions, the former existing primarily to ensure proper passage of the property and the latter being a mechanism to increase the efficient management of property and to minimize the costs of ownership.

84 See 4 W. HolDSWORTH, supra note 82, at 435.

85 "[T] $78, \S 3.2$. For further details on the creation of the use and the rights and responsibilities of the various parties, see $4 \mathrm{~W}$. HoldswORTH, supra note 82, at 421-43.

${ }_{86}$ Fratcher, supra note 77 , at 59.

87 See id.

${ }^{88}$ Among these scholars were Lord Chief Baron Sir Geoffrey Gilbert, Francis Williams Sanders, Sir William Blackstone, George Spence, and Sir Kenelm Edward Digby. See 4 W. HoldSWORTH, supra note 82 , at 410 .

89 Vasey, Fideicommissa and Uses: The Clerical Connection Revisited, 42 JuRIST 201, 203 (1982).

so See infra notes 99-121 and accompanying text.

91 $4 \mathrm{~W}$. HoldswORTH, supra note 82 , at 410 .

${ }^{82}$ See Thomas, supra note 5, at 162. 
Moreover, most scholars agreed that, had the use developed from the fideicommissum, no term other than fideicommissum would have been used. The word "use," on the other hand, was derived from the phrases ad opus and ad usum, signifying an origin independent of the fideicommissum. ${ }^{\text {9s }}$

Recently, however, the theory of the Roman origin of the trust has been revived. A fourth-century letter of Saint Jerome condemned the utilization of fideicommissum by priests to evade imperial restrictions on inheritance by the clergy. ${ }^{94}$ This letter was well-known up to the Middle Ages. ${ }^{95}$ The use was similarly employed by ecclesiastics in England to circumvent royal enactments limiting church holdings. ${ }^{96}$ This new-found evidence has led one scholar to reassert the conclusion that

since the Church had begun her evangelizing mission in an environment which was under the jurisdiction of Roman law, and therefore had borrowed much from that system, and since the use was the invention of ecclesiastics, versed in this jural discipline, . . . it is inescapable that considerable inspiration must have been drawn from Latin juridical sources. ${ }^{97}$

While this historical connection is interesting and may point to some minor influence of Roman law on the trust in England, the major criticisms of the theory remain unchallenged. As a strictly legal matter, the similarities between the fideicommissum and the use appear to be superficial..$^{88}$

\section{B. The Salic Salmannus}

The currently accepted theory among Western legal scholars as to the origin of the trust in England was promulgated at the end of the nineteenth century by Frederic William Maitland and Oliver Wendell

8s See Maitland, supra note 81, at 137. Ad opus, meaning "on someone's behalf, for someone's benefit" became os or oes in Old French and eventually "use" in English. See id. at 127, 131-32; see also Brown, supra note 79, at 359 (tracing ad opus through the Gallicization of al os and ues, as shown in the Domesday book, to "use"). This terminology was used in England long before the Norman Conquest. See Maitland, supra note 81 , at 128 . While the terms ad opus and ad usum were later used indiscriminately, ad opus is the original form indicating the use. See id. at 127.

94 See Vasey, supra note 89, at 202.

os See id. at 212 .

${ }^{96}$ See id. at 202.

97 Brown, supra note 79, at 365-66.

os See supra notes $90-93$ and accompanying text. 
Holmes.99 Maitland and Holmes attributed the trust to the Salic salmannus. ${ }^{100}$ Fifth-century Salic law ${ }^{101}$ employed a third party, known as a salmannus or, in an anglicized form, saleman, ${ }^{102}$ to aid in the transfer of property. ${ }^{103}$ The term salmannus is said to be derived from "sala," to transfer, the salmannus being "a person through whom effect is given to a transfer."104 Property was transferred to the salmannus for specific purposes to be carried out during the lifetime or after the death of the person conveying it. ${ }^{105}$ This occurred primarily in cases involving the appointment or adoption of an heir. ${ }^{106}$ Holdsworth describes the salmannus as the "ancestor of the executor," and points to the Germanic institution as the source of the doctrines of bailment and agency, as well as the use. ${ }^{107}$ A symbolic staff was passed from the donor to the salmannus who eventually presented the staff to the donee. ${ }^{108}$ This same ritual was to be found in the transfer of copyhold land in England. ${ }^{109}$ Thus, Maitland and Holmes theorized that "the saleman became in England the better known feoffee to uses."110 Like the feoffee to uses, the salmannus held property "on account of or to the use of another" and was "bound to fulfil his trust."111 Adoption of such an institution would give a landowner greater flexibility in the disposition of his property than was allowed under the restrictive common law of medieval England. ${ }^{112}$

This theory of Salic influence is strengthened by the fact that following the withdrawal of the Roman legions from Great Britain in the fifth century the primary racial infusions into England were Germanic, ${ }^{113}$ and the Norman conquerors of the eleventh century imported Salic law into England. ${ }^{114}$ The concept of the salmannus did not take

${ }^{99}$ See Holmes, Law in Science and Science in Law, 12 HaRv. L. REv. 443 (1899); Maitland, supra note 81.

${ }_{100}$ See Holmes, supra note 99, at 445-46; Maitland, supra note 81, at 129.

101 The Lex Salica was the legal code of the Salian Franks, a German tribe, promulgated by Chlodwig in the early sixth century. See A. Watson, The EvoluTION OF LAW 80 (1985); Holmes, supra note 99, at 445.

102 An alternate anglicized spelling is salman, and the German term is treuhand.

See $4 \mathrm{~W}$. HoldswORTH, supra note 82, at 410-11.

103 See Holmes, supra note 99, at 445-46.

$1044 \mathrm{~W}$. HolDSWORTH, supra note 82 , at $411 \mathrm{n} .1$.

105 See id. at 411.

${ }^{108}$ See Thomas, supra note 5, at 162.

$1074 \mathrm{~W}$. HolnswORTH, supra note 82, at 411.

${ }^{108}$ See Holmes, supra note 99, at 446; Maitland, supra note 81, at 129.

${ }_{109}$ See, e.g., Holmes, supra note 99, at 446.

110 Id.

111 W. HoldswORTH, supra note 82 , at 412.

112 See id. at 411-12.

11 See Brown, supra note 79, at 365.

114 See id. at 357. 
hold, however, until the "legal Renaissance of the twelfth and thirteenth centuries ... [ [when] we get the beginnings of the common law; and with the beginnings of the common law we can see the position which this idea of holding property on account of or to the use of another will take in it."11s

The theory, however, has been criticized by scholars of both Western and Islamic legal history as being based exclusively on a superficial resemblance. between the positions of the salmannus and the feoffee to uses, rather than any fundamental similarity between the two devices. ${ }^{116}$ For example, the role of the salmannus was strictly that of an intermediary for a conveyance, while the feoffee to uses acted more as a trustee. ${ }^{117}$ Further, such concepts as "the separation of usufruct from ownership, the creation of life estates, and the power of the original owner . . . to direct the passing of the usufruct from one beneficiary to another" were unknown to Salic law. ${ }^{118}$ Moreover, as one Western legal scholar has pointed out, use of a salmannus was not a usual form of conveyance in medieval England, among the Saxons or the Normans. ${ }^{119}$ It was apparently not a thirteenth-century practice to give a guardian legal estate over property. ${ }^{120}$ Nor does Bracton, the thirteenth-century English legal historian, make mention of the salmannus, although he describes other contemporary devices for the conveyance of property. ${ }^{121}$

\section{The Islamic Waqf}

\section{Cultural Contacts Between Islam and England}

Given the deficiencies in the prevailing theories, some scholars have turned to Islamic law for the origin of the trust. ${ }^{122}$ Sufficient contact existed between Islam and the West to warrant further investigation of such a theory. The emergence of the trust coincides with a period of increased contacts between Europe and the Muslim world. The very Franciscan Friars who are believed to have introduced the use in England were active in the Middle East. Saint Francis himself spent parts of 1219 and 1220 in Islamic territory. ${ }^{123}$ Pilgrimages to the Holy

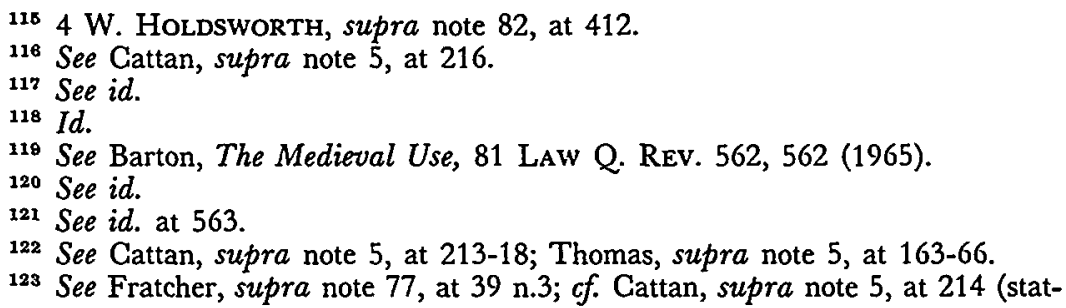


Land were quite common during the eleventh and twelfth centuries, while the Crusades, which lasted from approximately 1095 to 1291 A.D., sent tens of thousands of Europeans to the Middle East. ${ }^{224}$

Jerusalem was a particularly significant point of contact between England and the Muslim world because of the presence there of the Orders of the Templars and Hospitallers. ${ }^{125}$ These orders were religious/military organizations active during the Crusades. The Knights Templars were established in Jerusalem around 1120, remaining there until the end of the thirteenth century. ${ }^{126}$ The Templars established the principal House of their Order in London in 1128. ${ }^{127}$ The Order of the Hospitallers was founded in Jerusalem in the eleventh century. ${ }^{\mathbf{1 2 8}}$ These religious orders appear to have been quite influential in the development of the Inns of Court in fourteenth-century England. The Inns of Court were the successors to earlier law schools associated with churches, which had emerged between 1135 and $1189,{ }^{120}$ soon after the Templars established their London house. ${ }^{130}$ It has been theorized that these institutions were modelled after the Islamic college of law in its early form of a mosque with an adjoining inn, with which the Crusaders would have become familiar during their stay in Jerusalem. ${ }^{131}$ The example of the Inns of Court provides some evidence of the transmission of legal institutions from the Arab world to England. ${ }^{\mathbf{1 3 2}}$

ing that Saint Francis travelled to Egypt in 1219). One scholar dismisses the suggestion that the waqf was adopted from Byzantine charitable institutions and later transmitted to the West via Franciscan missions in the Middle East by stating that the waqf was indigenous to Islam. See Jones, Pious Endowments in Medieval Christianity and Islam, 109 Diogenes 23, 26-27 (1980). He does not, however, address the issue of the transmission of the waqf concept, whatever its origin, to the Franciscan Friars.

124 See Cattan, supra note 5, at 214-15; Crusades, in 5 ENCYClopedia BRITANNICA 297, 297 (1983).

${ }^{125}$ Makdisi, supra note 2, at 13-14.

128 See id.

127 See id. at 13.

${ }^{128}$ See id. at 13-14.

128 See id. at $12-14$.

130 See id. at 14-15.

131 See id. at 11-16.

132 For a list of corresponding elements found in Islamic and Western law and education, see G. MAKDISI, supra note 15, at 287-88. The legal field is not the only sphere in which such borrowing took place. Beginning in the tenth century, and reaching its height in the twelfth and thirteenth centuries, an active transfer of scientific and philosophical learning occurred between Islam and the West. See generally D. METlitzki, The MatTer of ARaby in Medieval England (1977); Gabrieli, The Transmission of Learning and Literary Influences to Western Europe, in 2 CAMBRIDGE HISTORY OF ISLAM 851 (1970); Runciman, Muslim Influences on the Development of European Civilization, in 3 SARKIYAT MECMAUSI 13 (1959). The main conduits for this transfer were Spain, Sicily, Africa, and Syria. See C. Haskins, The ReNaissanCE OF THE TWELFTH CENTURY 278 (1957).

Hellenic learning had been absorbed by the Arabs centuries before and to this 


\section{Comparison of the Waqf and the Trust}

The concept of the waqf would have been particularly welcome "in a country where . . . the lands were not 'testamentary or devisable." "133 Indeed, in England, the trust was almost immediately extended beyond charitable purposes to effect the settlement of family property. ${ }^{134}$

The similarities between the waqf and the early English trust are striking. As one scholar noted:

Under both concepts, property is reserved, and its usufruct appropriated, for the benefit of specific individuals, or for a general charitable purpose; the corpus becomes inalienable; estates for life in favor of successive beneficiaries can be created ... without regard to the law of inheritance or the rights of the heirs; and continuity is secured by the successive appointment of trustees or mutawallis. ${ }^{135}$

The same actors are found in both institutions: the waqif or settlor, the mutawalli or trustee, and the beneficiaries, both present and future. ${ }^{136}$ Indeed, because it was permitted to retain the feature of perpetuity with regard to application of the trust income even after the rule against perpetuities ${ }^{\mathbf{1 3 7}}$ limited the duration of other trusts, the English charitable trust is more similar to the waqf than to either the fideicommissum or the salmannus. ${ }^{138}$

The only significant distinction between the wagf and the English trust is the express or implied reversion of the waqf to charitable pur-

\footnotetext{
"Greek inheritance the Arabs added something of their own: observation of disease sufficiently accurate to permit of identification; large advances in arithmetic, algebra, and trigonometry . . . ; and the standard astronomical tables of the Middle Ages." Id. at 282. The works of many Muslim scientists and philosophers became quite well known in the West, among them the treatises of Ibn Sina (known as Avicenna in Europe) and Ibn Rushd (Averroes). See Runciman, supra, at 16-17. Islamic influence is also evident in the fields of art, architecture, and literature. See id. at 21-22.

${ }^{133}$ Cattan, supra note 5, at 214-15.

134 See id. at 213.

138 Id. at 212.

${ }^{136}$ See id. at 214.

137 John Chipman Gray's classic statement of the rule against perpetuities is that: "No interest is good unless it must vest, if at all, not later than twenty-one years after some life in being at the creation of the interest." J. GRAY, The Rule Against PerPETUITIES \& 201 (4th ed. 1942).

The indestructibility of executory interests which served as the impetus for the development of the rule against perpetuities was not established until 1620 , see Pells v. Brown, 79 Eng. Rep. 504 (K.B. 1620), and the Rule itself was not formulated until 1682, see Duke of Norfolk's Case, 21 Eng. Rep. 982 (Ch. 1682). Thus, at all times relevant to this comparison the rule had not yet been instituted.

${ }^{138}$ See G. MAKDISI, supra note 15, at 227.
} 
poses when its specific object has ceased to exist. ${ }^{139}$ This difference arises because of the invalidity under Islamic law of a wagf without an ultimate charitable purpose. ${ }^{\mathbf{1 4 0}}$ Such a distinction only arises, however, as between the Islamic family trust, wagf ahli, and a noncharitable English trust. The wagf khairi, on the other hand, was required to be devoted to a charitable purpose from its inception and therefore no reversion provision was required. ${ }^{141}$ Another difference is the English vesting of "legal estate" over the trust property in the trustee. However, while the trustee may nominally be the "owner" of the trust property, he is nonetheless bound to administer that property for the benefit of the beneficiaries. The role of the English trustee therefore does not differ significantly from that of the mutawalli. ${ }^{\mathbf{1 4 2}}$

Thus, it appears that the English trust bears a closer resemblance to the wagf than to the Salic salmannus. The waqf and the trust are remarkably similar in form, and ample opportunity for transmission of the Muslim institution existed at the very time the trust began to emerge in England. Surely so many coincidences should not be dismissed without further examination.

The next Part of this Comment will, therefore, analyze the 1264 Statutes establishing Merton College, Oxford, as essentially a wagf document.

\section{The 1264 Statutes of Merton Gollege, Oxford}

\section{A. Background}

Walter de Merton, the founder of Merton College, Oxford, was a

139 See Cattan, supra note 5, at 214.

${ }^{140}$ See supra notes 14,51 and accompanying text.

141 Note that whereas Islamic law required the wagf income ultimately to be dedicated to a charitable purpose, see supra notes 14, 51 and accompanying text, English law simply permitted the income from a charitable trust to be applied in perpetuity. See 1 A. ScoTr, supra note $78, \S 62.10(2)(f)$. The comparison is strengthened, however, by the existence in English law of the doctrine of cy pres. When applicable, cy pres leads to the continuation of a charitable trust in perpetuity after the specific charitable dedication has lapsed. Thus, a charitable remainder is judicially substituted for reversion to the settlor's heirs. Cy pres applies, however, only when the court finds that the settlor had a general charitable intent. See 4 A. Scort, supra note 78, § 399.

The fact that both systems possess doctrines preserving the charitable quality of the trust again illustrates the marked similarities between the Islamic law of wagf and English law governing trusts. Granted, the English doctrine can be distinguished from that existing in Islam. Specifically, cy pres "aims at a judicial determination of a particular [charitable] purpose," while no such machinery is necessary in Islamic law because "appropriation of the benefit of the waqf to the poor . . . is considered to be a [valid] residuary charitable object of [any] waqf." Cattan, supra note 5, at 209. Nevertheless, the shared purpose of both doctrines remains undisturbed.

142 See Cattan, supra note 5, at 212. 
thirteenth-century English clergyman and government servant. At the time of his death, de Merton was serving as Bishop of Rochester. He had three times held the powerful position of Chancellor of England, in 1258,1260 , and $1272 .^{143}$

As early as 1240 , Walter de Merton was using the New Temple to conduct business transactions and as a depository for his wealth. ${ }^{144}$ The New Temple was the English headquarters of the Knights Templars, a well-known "centre of royal, diplomatic, legal and fiscal activity and a treasure-house of valuables, documents and large sums of money." 145 Throughout the twelfth and thirteenth centuries, the Templars had significant contacts with the Middle East, and particularly with Jerusalem. ${ }^{146}$ Indeed, by 1338 , the Temple had evolved into one of the Inns of Court, ${ }^{147}$ which may have been patterned after a typical waqf institution, the Islamic college of law. ${ }^{148}$ Thus, Walter de Merton may have been somewhat familiar, directly or indirectly, with the form of the Islamic charitable trust.

Walter de Merton undoubtedly had some contact with Crusaders and other visitors to the Middle East as a necessary part of his duties as Chancellor. During his term of office in 1258, de Merton was responsible for "settl[ing] with the pope's legate the grant of the kingdom of Sicily from the pope to Edmund, Earl of Lancaster, the king's son." ${ }^{149}$ Sicily was a significant conduit for Islamic culture to England due to the constant exchange of "administrative personnel between Norman England and Norman Sicily." 150 Sicily had been under Muslim dominance from 902 to 1091, but there was no significant transfer of Arab culture to Europe via Sicily until after the Norman Conquest at the end of the eleventh century. This influence was particularly strong during the reigns of Roger II (1130-54) and Frederick II (121550) of Sicily. ${ }^{151}$ In 1262, while de Merton was again serving as Chancellor, Henry III was absent from England and "ignorant of his kingdom's affairs, [with] even his secretary . . . looking to the Chancellor

${ }^{143}$ B. Henderson, Merton College 2, 20 (1899). For biographies of Walter de Merton, see J. Highfield, supra note 2, at 5-34; E. HobHOUSE, supra note 3.

144 See J. Highfield, supra note 2, at 12-13.

${ }_{145}$ Roxburgh, Lawyers in the New Temple, 88 LAw Q. REv. 414, 414 (1972).

${ }_{148}$ See supra notes $125-31$ and accompanying text.

${ }^{147}$ See Roxburgh, supra note 145, at 427-28.

148 See Makdisi, supra note 2, at 11-16; supra notes 129-31 and accompanying text.

148 E. HobHouse, supra note 3 , at 5.

160 See Makdisi, supra note 2, at 14. 19.

151 See D. MeTLITZKI, supra note 132, at 7; Runciman, supra note 132, at 18- 
at home for commands."152 During de Merton's final term in office, he again wielded unusual power, being described as "practically Regent of the Kingdom" while Edward I was on Crusade in the Holy Land. ${ }^{153}$ Surely, Walter de Merton's position of authority would have involved him in relations between the Middle East and England, particularly during the era of the Crusades.

Walter de Merton's foundation went through a number of stages before it attained its status as "a watershed in the history of colleges."154 Concerned with the provision of a university education for his nephews, in 1262 de Merton obtained a license from his feudal overlord to vest certain properties for the support of university students. Such a procedure was not uncommon. ${ }^{155}$ While this assignment was intended to provide benefits in perpetuity, the endowment was not incorporated. ${ }^{158}$ The transaction was embodied in an "ordinatio,"167 which is no longer extant. However, de Merton had reserved to himself the right to modify the terms of the ordinatio, and, in 1264, he availed himself of that right. ${ }^{158}$ The result was the 1264 Statutes of Merton College. ${ }^{159}$

In 1270, Walter de Merton effectively reissued these statutes, apparently to confirm the establishment of the trust, which had been created during a period of civil strife. ${ }^{100}$ These statutes also added a number of properties to the existing trust but made no essential changes in the structure or governance of the College. ${ }^{\mathbf{1 6 1}}$ Later, in 1274, a new set of statutes was adopted. This latter document is generally credited with establishing the modern college system. ${ }^{162}$ Prior to 1274 , Merton was an unincorporated charitable trust. ${ }^{\mathbf{1 8 3}}$ In contrast, the statutes of 1274 allowed the academic community to govern itself. ${ }^{164}$ Thus, after 1274,

182 E. Hовноuse, supra note 3 , at 7.

153 B. Henderson, supra note 143, at 20.

154 G. MAKDISI, supra note 15 , at 237.

165 See Merton Muniments 8-9 (P. Allen \& H. Garrod eds. 1928).

${ }^{18 B}$ See E. HoBhouse, supra note 3, at 11.

167 An ordinatio is the "prescription, ordaining (of what should be done)." OxFORD LATIN DictionaRy 1265 (1982). The ordinatio discussed here is a document arranging for the disposition of property.

168 See Merton Muniments, supra note 155 , at 10.

169 The original Statutes were prepared in Latin. See 1 STATUTES of THE ColLEGES OF OXFORD 5-9 (E. Bond. ed. 1853). This analysis is based on a translation by the Reverend John Miller of St. Charles Borromeo Seminary, to whom the author extends her thanks. For a full English text of the Statutes, see Appendix, infra.

160 See G. Brodrick, Memorials of Merton College 6 (1855).

161 See E. HobHouse, supra note 3, at 34-35.

162 See G. BRODRICK, supra note 160 , at 6 .

163 See Makdisi, supra note 2, at 15.

164 See J. Highfield, supra note 2, at 54. 
Merton was an incorporated college, the first such institution. ${ }^{165}$ As of 1264, however, the structure of Merton College fit well within the wagf tradition, ${ }^{166}$ as did the Inns of Court, which continue to this day as unincorporated guilds. ${ }^{167}$ Admittedly, after 1274 Walter de Merton's trust was outside the wagf tradition, having been incorporated. However, the statutes of 1264 can nevertheless be analyzed as a waqf instrument.

\section{B. Analysis}

\section{Similarities of Purpose and Structure}

The 1264 statutes begin with an invocation to "God, the almighty Father, and ... the Son and ... the Holy Spirit, in honor of the same holy and only Trinity, and of the most blessed Mary, Mother of God, of St. John the Baptist Precursor of the Christ, and of all the Saints." "W68 Walter de Merton then expressed his intention to "grant, assign, and concede [the manors of Maldon and Farleigh] with all that

${ }^{186}$ See G. MAKDISI, supra note 15, at 228; Makdisi, supra note 2, at 15.

${ }^{168}$ Some scholars contend that Merton College was incorporated as of 1264 . See, e.g., G. BRODRICK, supra note 160 , at 5 ; B. HENDERSON, supra note 143 , at 8; E. HobHouse, supra note 3, at 12; Merton Muniments, supra note 155 , at $9-10 ; 3 \mathrm{H}$. Rashdall, The Universities of Europe in the Middle Ages 192-93 (1936). These scholars, however, may have spoken prematurely. As Highfield points out in his more recent work:

In 1262 the protecting shadow of the priory is there. In 1264 the earl of Gloucester and bishop of Winchester were relied on as underwriters. But by 1274 all three have vanished; and, though the king and Richard, King of the Romans, have been brought in as benefactors, they play no part in the arrangements. In case of extraordinary circumstances the new visitor, the archbishop of Canterbury, could intervene and he held the appellate jurisdiction. But in all ordinary business the community was to run its own affairs. The fully self-governing Oxford college had been born.

J. Highfield, supra note 2, at 54.

This observation is fully supported by a comparison of the Statutes of 1264 and those of 1274. While the Statutes of 1264 gave the beneficiaries a role in the administration of the College, they were generally powerless to change the terms of the trust. Flexibility was allowed only with regard to the number of scholars to be admitted to the College. See Appendix at 1259. Not only was the administrative role of the beneficiaries greatly expanded under the Statutes of 1274, but that document also gave the warden and a committee of scholars virtual carte blanche to enact new statutes "promot[ing] the well-being and preservation of the existing institution." G. BRODRICK, supra note 160 , at 338 . The full text of the 1274 Statutes is available in Latin in 1 STATUTES OF THE Colleges OF OXFord, supra note 159, at 23-27, and in English in G. BRODRICK, supra note 160, at 317-40. Thus, characterizing the Merton College of 1264 as a "self-governing corporate secular community," B. HENDERSON, supra note 143 , at 8 , would appear to be incorrect.

167 See Makdisi, supra note 2, at 15.

168 Appendix at 1257. 
pertains to them by whatever name they might be known for the founding of a House which I desire to be called and named 'House of Scholars of Merton." "168 This House was to be established "for the support in perpetuity" of students at the University of Oxford or elsewhere, along with a number of clergymen. ${ }^{170}$ Thus, in the opening sentences of the statutes, de Merton set forth a charitable purpose for his trust and assigned properties for the support of that object. These elements are familiar from an examination of the Islamic waqf. A waqf was invalid without a charitable purpose ${ }^{171}$ and the assignment of property was required to be in perpetuity. ${ }^{172}$ Other conditions of the waqf were fulfilled as well; the property assigned here was tangible and immobile, and it yielded an income. ${ }^{173}$

Walter de Merton then went on to set forth the first condition of the trust, that "the aforementioned students be of our kin, so long as they are found to be honest and able, willing to advance in [such studies]."174 Indeed, any member of the founder's family "lack[ing] what is needed for survival" was to be supported by the trust in return for appropriate service. ${ }^{175}$ This provision was in keeping with Islamic practice. As discussed above, Islam recognized two types of awqaf, the waqf khairi and the waqf ahli. ${ }^{178}$ Walter de Merton's trust, even with the provision for the support of his family, fits best with the wagf khairi tradition. A waqf ahli typically directed the trust income to family members, with the charitable purpose coming into play only upon a triggering event such as the passing of a certain number of generations. ${ }^{177}$ The wagf khairi was the form used to establish an institution such as a madrasa, or college of law. Given that the focus of de Merton's trust was the foundation of a college, it would seem best categorized as a waqf khairi. The designation of certain family members as beneficiaries, however, would be well within the Islamic concept of founder's discretion. ${ }^{178}$ Here, the ultimate charitable purpose was the support of indigent scholars, for when twenty eligible family members

$169 \mathrm{Id}$.

170 Id. Oxford had become known as a center of academic activity in the twelfth century. For a discussion of the origins of Oxford University, see Vaughn, The Origin and Early Development of the English Universities to the Close of the Thirteenth Century, 2 U. Mo. STud. 1, 22-40 (Social Science Series 1908).

171 See supra notes 14,51 and accompanying text.

172 See supra notes $27-28$ and accompanying text.

${ }^{173}$ See supra notes $34-35$ and accompanying text.

174 Appendix at 1257.

$178 \mathrm{Id}$. at 1260.

${ }^{178}$ See supra notes $13-14$ and accompanying text.

177 See id.

${ }^{178}$ See supra note 43 and accompanying text. 
could not be found, "other honest and able [students] . . . may fill the vacant places." 179 The enunciation of qualifications for appointment as a beneficiary was significant under Islamic law, for a founder could only empower the mutawalli to accept or reject applications based on express criteria, not at the trustee's discretion..$^{180}$

\section{Shared and Contrasted Provisions}

The founder next set forth the income each beneficiary was to receive as "at least forty shillings each year or fifty in four parts, if the foundation renders a sufficient amount."181 This language allowed the warden, trustee of the House, a certain degree of flexibility, for the provision seems to establish a floor, rather than an absolute figure, on the amount of income to be paid to beneficiaries. Such flexibility was advocated by Muslim jurists, who recommended that "the mutawalli . . . keep the amounts unspecified, because the income of the endowment fluctuated. This would allow him always to meet his obligations by dividing the income either equally . . . or according to a scale."182

The students were to "live together hospitably ... dressed in a similar way as a sign of unity and mutual affection."183 Such provisions regarding attire were apparently found in wagf documents because they were a topic of controversy among Muslim jurists. One noted Muslim jurist, for example, condemned dress codes as being without spiritual or material benefit. ${ }^{184}$ Walter de Merton further provided that each student was to receive his full share of income, "so long as [he] behave[d] well and honestly." 185 But, the founder cautioned that "if any one of them should give up, or take on the religious habit, or transfer allegiance to others, or come upon richer benefices," his award was to be withdrawn. ${ }^{186}$ Such clauses were common in waqf instruments, particularly those establishing academic institutions. Founders often stipulated in the wagf document that "their beneficiaries were not to benefit from other waqfs"; this was considered necessary because "the 'professional' student was already in existence and knew how to make the best of the situation."187 Similarly, de Merton stipulated that a beneficiary could be dismissed and replaced if he should "withdraw from study, or be

178 Appendix at 1257.

180 See G. MAKDISI, supra note 15, at 49.

181 Appendix at 1257.

182 G. MAKDISI, supra note 15 , at 71 .

189 Appendix at 1258.

184 See G. MAKDISI, supra note 15 , at 36.

188 Appendix at 1258.

186 Id.

187 See G. MAKDISI, supra note 15, at 61; see also supra note 71 . 
unwilling to apply himself to study to the best of his ability, or become publicly known for bad behavior."188 Unlike the typical Islamic provisions for dismissal, however, the statutes left dismissal of a beneficiary and selection of his replacement to the scholars themselves, although in case of disagreement, the chancellor of the university or warden of the House were to elect a new beneficiary based on the recommendations of "six or seven of the older and wiser students." gives more authority to the beneficiaries than was commonly found in the waqf, ${ }^{180}$ it does not violate any of the principles underlying the Islamic charitable trust. ${ }^{101}$

In the same vein, Walter de Merton urged that the students

inquire diligently in whatever ways they can whether the warden of the above stated House has conducted himself well, honestly, and prudently in the administration of the goods and possessions of the same; and [it will be permissible], if the opposite comes to light, to report it to the one who has the responsibility of correcting such things. ${ }^{\mathbf{1 0 2}}$

An unfit trustee was to be relieved of his post. This provision is similar to Islamic law, which allowed those beneficiaries named in the waqf instrument to examine the accounts of the trustee. ${ }^{103}$ The beneficiaries could also demand that the mutawalli perform needed repairs. ${ }^{194}$ Thus, as with the waqf, the Merton documents encouraged the beneficiaries to investigate the terms and conditions of the trust, although they could not act independently to enforce its provisions. As under Islamic law, that power was vested in an overseer.

The duties of the warden were "to serve the interests of the abovementioned House as though they were his own, in every instance, with the most prudent counsel possible, and to the extent his energies truly and honestly permit, to promote the same [interests]."195 This is comparable to the duty of the mutawalli to administer the wagf according to the stipulations of the waqf instrument and for the benefit of the designated beneficiaries. ${ }^{196}$

Walter de Merton also made provision for an increase in the num-

188 Appendix at 1258.

188 Id.

180 See supra notes 70-76 and accompanying text.

191 See supra notes 23-36, 42-49 and accompanying text.

192 Appendix at 1258.

193 See supra notes 75-76 and accompanying text.

194 See G. MAKDISI, supra note 15 , at 60.

185 Appendix at 1259.

${ }^{196}$ See supra notes 56, 60-62 and accompanying text. 
ber of scholars to be supported by the trust. ${ }^{197}$ Similarly, a wagf instrument could validly reserve power to the founder or subsequent trustees to "make alterations and amendments" in the terms of the trust. ${ }^{198}$ Under Islamic law, such a right could be exercised only once "unless the waqf instrument specifically provides that it may be exercised on repeated occasions." 189 Here, the statutes provide that the number of beneficiaries may be increased "as often as [the possessions and goods of the House increase] through the Lord's goodness."200

The statutes also prescribe a method for the selection of subsequent wardens. The twelve eldest scholars of the House were to nominate a candidate, who was then to be approved by the Bishop of Winchester. ${ }^{201}$ This procedure falls short of that found in some waqf instruments: "a waqf could be instituted in the care of a definite number of men who then appointed the mutawalli without prior consultation with the qadi."202 In contrast, under the Merton documents, "both the appointment and the removal of said warden . . . pertain to [the Bishop] as the special protector, father, and defender of the said students." ${ }^{203}$ Presumably, therefore, the Bishop had the ultimate responsibility of correcting problems in the administration of the trust and was the one to whom the scholars were instructed to appeal. Being vested with this authority, it appears that the Bishop acted in the same general supervisory capacity over Walter de Merton's trust as the qadi did over the waqf. ${ }^{204}$

\section{Summary}

The structure of Merton College as embodied in the 1264 statutes explicitly fulfills a number of the conditions necessary for the establishment of the waqf, while not violating any of the principles underlying the Islamic institution. Some of the conditions of Walter de Merton's trust may have been atypical of the waqf form but clearly were not prohibited. And it must be remembered in this regard that, under Islamic law, the founder could exercise considerable discretion over the terms of the trust. Were the Merton documents written in Arabic, rather than Latin, the statutes could surely be accepted as a waqf

197 See Appendix at 1259.

198 Cattan, supra note 5 , at 210.

199 Id. at 211 .

200 Appendix at 1259.

201 See id. at 1260.

${ }^{202}$ G. MAKDISI, supra note 15, at 52 (emphasis added).

203 Appendix at 1260.

${ }_{204}$ See G. MAKDISI, supra note 15 , at 52 ; see also supra notes $63-69$ and accompanying text. 
instrument.

Western scholars have struggled to explain the source of Walter de Merton's design. The titles and terminology he used and the numerical makeup of the trust have been attributed to an admittedly "very diverse" group of existing monastic and academic institutions. ${ }^{205}$ The wagf has been entirely overlooked in these analyses. Yet, it would seem more reasonable to theorize that de Merton derived the form of his trust from a single source, the Islamic waqf, rather than such varied institutions.

Indeed, Walter de Merton's purposes in establishing the College may have been like the motives that inspired Muslim founders. Clearly, Walter wished to advance education and to support family members. But the wagf form was also used by wealthy Muslims to avoid confiscation of property. ${ }^{206}$ Walter also had experienced such difficulties; prior to 1264, his estates had twice "been occupied and ravaged [by supporters of the baronial regime] because of his . . . position as one of the highest officials of the king." 207 These events may have prompted Walter to separate the property from his personal fortune.

\section{ConCLUSION}

While this analysis has pointed to a number of similarities between the waqf and the trust as it emerged in thirteenth-century England that may be indicative of Islamic influence, it is in no way determinative of such influence. Walter de Merton nowhere openly expressed an intent to imitate the waqf. However, such silence is to be expected. Merton College was established during the Crusades, and it would not have been wise for a prominent clergyman and government servant to announce his adoption of an Islamic institution. ${ }^{208}$ Moreover, de Merton need not have been conscious of the Islamic influence upon the trust. Rather, he could have adopted the Islamic system indirectly, via the Inns of Court or the Franciscans, for example.

Nevertheless, this examination should serve to raise questions about the existence and extent of Islamic influence on the development

208 J. HighField, supra note 2, at 69.

${ }_{206}$ See supra notes 51-53 and accompanying text.

${ }^{207} \mathrm{~J}$. HighField, supra note 2 , at 25.

${ }_{208}$ This is particularly true since "the keynote of the unvaried theme which resounded throughout the Middle Ages and persisted to the Renaissance . . . [was that] the Saracens must be punished for their unbelief." D. MetLITZKI, supra note 132, at 14. Such hostility, however, does not preclude legal borrowing: "[T]ransplants occur in great number, . . . the recipient society may have very different values from the donor, and . . . the reasons justifying the acceptance of the foreign law may be different from those that created it in the first place." A. WATSON, supra note 101, at 73-74. 
of Western, and specifically English, law. Indeed, certain similarities between Islamic and English law would have facilitated borrowing by the English:

Both legal systems were indigenous, national laws; both were based on custom; unlike civil (Roman) law and canon law, they were not codified laws; each in its own peculiar way was a judge-made law, following a case-law method, and the courts of each were characterized by a jury system of sworn witnesses, familiar with the facts of the case. ${ }^{209}$

But the possibility of Islamic influence on Western law has generally been ignored. While the similarities between the waqf and the English trust were pointed out in a law journal as early as $1949,{ }^{210}$ few Western legal scholars appear to have seriously examined the issue.

Clearly, the origins of and influences on existing Western legal institutions is a worthwhile field of study. Ultimately, however, it may be of secondary importance. As one scholar of Islamic law noted, "it is of much greater import that the comparative study of these two developments, each unique in its own right when taken over the whole course of its history, is capable of shedding light on both developments, the result being an enhanced understanding of their histories."211 Such an "enhanced understanding" should be the goal of comparative legal scholarship.

209 Makdisi, supra note 2, at 16.

${ }^{210}$ See Thomas, supra note 5.

211 Makdisi, supra note 2, at 11. 


\section{APPENDIX}

Statutes of The House of Scholars of Merton, in Maldon, 1264

In the name of God, the almighty Father, and of the Son and of the Holy Spirit, in honor of the same holy and only Trinity, and of the most blessed Mary, Mother of God, of St. John the Baptist Precursor of the Christ, and of all the Saints, I, Walter of Merton, one time Chancellor of our Lord Henry, King of England and son of King John, both by the authority granted to me by the said Lord my King and by reason of the right and power which devolve upon me in my manors of Maldon and Farleigh with all that pertains to them, I grant, assign, and concede these very manors with all that pertains to them by whatever name they might be known for the founding of a House which I desire to be called and named "House of Scholars of Merton," which also, for the good of the Holy Church of God, for the repose of the soul of the aforesaid Lord my King and for the souls of Lord Richard one-time Bishop of Dunelmensis, of Richard the one-time Count of Gloucester and Hertford, of Gilbert his son, of William of Wateville, and of Peter of Cuddington, as well as of my parents and all my benefactors, by the authority of the venerable father John of Winchester, the bishop of the diocese, and with the consent of his canonical chapter, I erect, found, and establish in the said manor of Maldon for the support in perpetuity of twenty scholars attending the schools of Oxford or wherever else it is appropriate for them to pursue studies and for the support of two or three ministers of the altar of Christ resident in said House, according to the condition and manner to be described both for the students and the aforementioned ministers and by the grace of God to be observed thenceforth. Concerning the aforementioned students I erect this condition:

To wit, [I erect] the succession which was due my heirs according to the custom of the kingdom in the said manors, for the everlasting benefit of holy Church and of our race, for the perpetual praise of our Maker, which I desire and choose to increase and continue in this very race, and thus I modify it, in the sight of God, that the aforementioned students be of our kin, so long as they are found to be honest and able, willing to advance in it. When, however, the full complement of twenty cannot be found, other honest and able [students], especially from the diocese of Winchester may fill the vacant places. Each of the same students will have at least forty shillings each year or fifty in four parts, if the foundation renders a sufficient amount; they are to receive this amount through the hands of the warden of the House at reasonable 
times annually. They shall live together hospitably, without detriment to their instruction, dressed in a similar way as a sign of unity and mutual affection. The students are to have such support fully and integrally, so long as they behave well and honestly: in such wise that if any one of them should give up, or take on the religious habit, or transfer allegiance to others, or come upon richer benefices, withdraw from study, or be unwilling to apply himself to study to the best of his ability, or become publicly known for bad behavior, or in any other way behave less than well and honestly, and all of this be evident to his associates, let the said support be taken from him, and let others of the said descendency or others, as has already been mentioned, freely succeed to him who, through the aforementioned scholars will be named from the aforementioned kin according to their wonted fidelity, so long as they are found to be able and honest. And if perhaps in such a nomination there is no agreement, then the Chancellor or the Rector of the University which they happen to attend, or the warden of the House, if the Chancellor or the aforesaid Rector do not attend to the matter within a month, should decide to admit those to this support whom on the advice of six or seven of the older and wiser students, under oath, they find very honest and able. Those moreover who have lost the said support through their own fault or from whatever other cause mentioned above will have no claim against the warden of the above-mentioned House or others, so long as it is evident that they were deprived of the said support through their own fault or other of the above-mentioned causes. But if any children of the said kin who have lost their parents or otherwise, because of the inadequacy of their parents, lack the necessary support for fundamental instruction, the warden himself, if means are sufficient, should see to their education in the said House, until they should be ready for schooling, if they are found able for it; and let those who shall be found able and worthy be taken into the consideration expressed above. Each year, moreover, on the Feast of the Exaltation of the Holy Cross, let ten or eight of the older and wiser students come together in the aforementioned House as the representatives of all; there for eight days, if they will, as a token of ownership which belongs to them by virtue of the said support, to spend time in the name of those for whom the very House takes its name. It will also be permissible for them to inquire diligently in whatever ways they can whether the warden of the above-stated House has conducted himself well, honestly, and prudently in the administration of the goods and possessions of the same; and [it will be permissible], if the opposite comes to light, to report it to the one who has the responsibility of correcting such things. In the same way, moreover, and 
at other times of the year, it will be permissible for two or three of the said students to conduct this kind of investigation and reporting as often as it seems necessary.

The warden, however, from the time he may be found to be less dedicated or able, may have no claim over his post; but let him lack every claim which he might think would belong to him. If, however, he perseveres in the aforementioned administration in an excellent and praiseworthy manner but becomes worn out from age or labor or in whatever other way, so that he is no longer able to fulfill the administration, from that time forward, for the rest of his life, let the older and stronger among the brethren of the same House fully and properly provide all that is necessary in food and clothing for him in the said House. He will be held, moreover, to serve the interests of the abovementioned House as though they were his own, in every instance, with the most prudent counsel possible, and, to the extent his energies truly and honestly permit, to promote the same [interests]. But if through the Lord's goodness it should happen that the possessions and goods of the said House increase, whereby the number of students with the necessary support might increase, then, as often as this should happen through the Lord's goodness, let the number of students increase in proportion to the increased means, and the number of ministers of Christ's altar of advancing age as well, if means are sufficient, for the honor of the divine name. The warden of the said House and the ministers of the altar living there, as well as ten students themselves, when they come together there in the above-mentioned manner and occasion, are to be content with bread and beer and an adequate portion of meat or fish without complaint; it may of course be necessary to provide more richly given guests or other demands. The number of students, however, should not be any the less increased, but let the warden and the brethren living there always have concern for the fruit which can be expected of these kinds of students for the future; and let them be more concerned to increase [this kind of fruit] than to satisfy their own desires, even if it should be due them as authorities and ministers by virtue of the present disposition or of the institution itself.

If, however, it should happen that one or more of the residents in the said House as described becomes ill, let nourishing foods be served to him through the period of this convalescence; if, however, he does not recover within a quarter part of the year or if illness continues to keep him there, the warden will be able to withhold temporarily that portion of money which would have kept the student in school, unless the means were enough for both. If, however, he gets better within the quarter part of a year, let nothing be withheld for that period of time. 
If, however, the aforesaid illness is incurable, so that the student would not be strong enough to pursue study or otherwise honestly provide for his needs, and he is of our kin, then for the sake of my descendency, which I am transferring to the aforesaid students, let them provide food and clothing for the rest of his life in the said House. But if any members of my family, after my death, should lack what is needed for survival, and were not otherwise provided for, then let them be adequately provided for in said House for the rest of their lives as they deserve; therefore, they are able to fulfill their duty by serving in appropriate ways according to their abilities. When there is need of a new warden for the said House, let him be nominated by the twelve eldest of the aforesaid students on the recommendation of the brethren of the House, who, with eternal reward in mind and free of every human consideration, take every pain to nominate one who will be esteemed to be among the best and the most faithful in the administration of goods and the interests of the said House, by the generosity of God. And let him shortly thereafter be presented by them to the Lord Bishop of Winchester, who is to commit to him the care of the said House, if he finds him worthy. The aforementioned bishop, with the mercy of God and the good of the Ghurch in mind, is to show grace and favor to the aforementioned students, as well as to the memory of the House both in appointing the warden of the same House and in removing him, should it become necessary, as well as in other interests of the same House: both the appointment and the removal of said warden as stated above pertain to him [the Bishop of Winchester] as the special protector, father, and defender of the said students.

Moreover, I enjoin the said students by the power of God and in the hope of gaining life here and hereafter that when they enter good fortune by the Lord's goodness, they diligently promote the said House in permissible and honest ways and that they diligently come to its defense and the defense of those who belong to it, whenever it is necessary. Let him also be always devoted to the House of Saint John the Baptist at Basingstoke, which the above-mentioned Lord King has founded and established in my territory at the instance of my prayers for the sustenance of ministers of the altar and of the sick poor; and let them increase it according as God inspires them and provides them with the means. Let them moreover be always grateful to the House of Merton, from which they take their name, and let them be eager to honor it as the helper of this work. Once or twice every year let them come together in places where they can do so, and let them have the divine mysteries celebrated for its founder and for its other benefactors living and deceased; at that place let them have the list of them recited 
as a memorial and in continuance of this charity, and let them pray for the cause of the most holy Church, and let them be diligent to increase the honor of their Maker and the praise of His name with all their heart. Let them faithfully and fully render account of their service to the lords of the fief, unless by their own free will they have come to remit it [the fief] in whole or in part. Moreover, this is to be attended to: if, for the benefit of the said students and brethren, a dwelling place at Farleigh or elsewhere in this territory should prove more fitting because of the location or other unforeseen reasons and they move to such a place or are moved through the offices of another helper of this work, none of their rights or possessions in the said manors or other things granted them is to be lost, nor anything which thereafter should be granted to them through the generosity of the faithful; so long as they hold and care for this institution; whether in fact or in name, they must not join themselves or their possession to another college.

For the everlasting memory of this foundation, and that the arrangement and healthy provision might have the strength of perpetuity, I have taken care to attach the seals of the aforementioned Lord Henry, the King, and of the Lord John, Bishop of Winchester, as well as of his chapter in witness of their consent and approval, to all present, together with my seal. Given in the twelve hundred and sixty-fourth year of the Lord. 
